\title{
The use of natural microphytobenthic assemblages as laboratory model systems
}

\author{
Emma C. Defew*, David M. Paterson, Scot E. Hagerthey \\ Sediment Ecology Research Group, Gatty Marine Laboratory, University of St Andrews, Fife KY16 8LB, Scotland, UK
}

\begin{abstract}
The use of complex species mixtures is becoming more common in laboratory investigations of ecological theory. Natural assemblages of microphytobenthos provide a model system of considerable species richness that can be examined and manipulated easily under laboratory conditions. However, the relative temporal stability of these assemblages maintained under laboratory conditions in terms of species composition and community metabolism is not known. This information is required before the results from model systems employing assemblages of microphytobenthos can be properly interpreted. Natural assemblages of microphytobenthos were sampled, prepared and incubated in the laboratory under light levels representative of those found in the literature. Analysis of microphytobenthic assemblage composition (gross community change), biomass (chlorophyll a), composition of pigments and photophysiological status were assessed after a $14 \mathrm{~d}$ period. No changes in species richness were found, whilst diversity declined from the initial field values, but were similar when compared between assemblages maintained at different light levels. Field assemblages contained greater numbers of larger diatoms compared to the cultured assemblages. Photophysiological responses were similar between the 2 light treatments, although signs of photophysiological stress were observed. It was therefore shown that estuarine microphytobenthic assemblages appear to possess a certain degree of inertia when brought from the field into the reduced light regime of a laboratory. Microphytobenthic assemblages therefore provide a useful experimental model with relevance to natural conditions.
\end{abstract}

KEY WORDS: Microphytobenthos $\cdot$ Laboratory culture $\cdot$ Mixed assemblages $\cdot$ Diatoms $\cdot$ Species diversity

Resale or republication not permitted without written consent of the publisher

\section{INTRODUCTION}

The deposition of fine sediments in the intertidal zone of estuaries forms highly productive mudflats. In most cases, single-celled phototrophic algae belonging to the Bacillariophyceae (diatoms) dominate the microphytobenthos of these sediments (Admiraal 1984, Paterson \& Hagerthey 2001). Diatoms are often the main primary producers in these systems, with primary production estimates ranging between 29 and $234 \mathrm{gC}$ $\mathrm{m}^{-2} \mathrm{yr}^{-1}$ (Underwood \& Kromkamp 1999). Diatoms also provide an important food resource for benthic infauna

*E-mail: ecd2@st-andrews.ac.uk such as Hydrobia ulvae, Corophium volutator and Nereis diversicolor. The presence of biofilms has generic effects such as the control of nutrient fluxes over the sediment-water interface (Sundbäck et al. 1991) and the mediation of sediment properties (Paterson 1995).

Estuarine ecosystems are a reservoir of genetic and species diversity, and provide a variety of ecosystem goods and services (Dickinson \& Murphy 1998). The accelerating effects of human activities on functional redundancy, biodiversity and the possibility that the loss of biodiversity may impact on ecosystem function has led to an increased interest in the stability or resistance of communities to environmental perturbations (Begon et al. 1990, Peterson et al. 1998, Tilman 1999). Diatoms have a rapid doubling time and respond quickly to 
changes in environmental conditions. As a result, microphytobenthic assemblages can potentially provide a model system that can be successfully manipulated to illustrate the potential effects of environmental change (McCormick \& Cairns 1994, Petchey et al. 1999) or ecosystem stress (Medley \& Clements 1998). In addition, because of their species-specific ecological sensitivities, the responses of these microorganisms may also reflect long-term dynamics through drift in species composition (Cameron 1995, Bennion et al. 1996).

Understanding the effects of system change on organisms and assemblages is complex. The ultimate goal is to determine, and then predict, how assemblages will react to stress in nature. The reductionist approach is to examine the response of single populations (Kromkamp \& Limbeek 1993, Staats et al. 2000) or reduced diversity mixtures to specific controlling factors under controlled conditions (van Donk \& Kilham 1990, Metaxas \& Lewis 1991, Olaizola \& Yamamoto 1994, Watermann et al. 1999, Underwood \& Provot 2000). The wider interpretation of these studies must always be treated with caution since natural assemblages contain the possibility of so many interactions and responses. Ideally, experiments should be conducted in the field with natural populations, but this is rarely possible. A compromise is to maintain a diverse natural assemblage under laboratory conditions: 'a natural assemblage culture'. Microphytobenthos provide a convenient model, since assemblages are species-rich and samples easily manipulated. However, assemblages will begin to change immediately upon removal from their ambient conditions. With respect to microphytobenthos, it is not known how fast these changes occur under normal laboratory conditions. Many factors (i.e. nutrients, grazing pressure, tidal flooding) are altered on removal from the field, but light availability is arguably one of the most fundamental changes when an assemblage is moved from the field into a laboratory system. Generally, light levels in laboratory systems are much lower than in the field and range between 50 and $200 \mu \mathrm{mol} \mathrm{m} \mathrm{m}^{-2} \mathrm{~s}^{-1}$ (Admiraal 1977, Glud et al. 1992, Hay et al. 1993, Madsen et al. 1993, Peletier et al. 1996, Serôdio et al. 1997, Smith \& Underwood 1998).

This study aims to investigate the resilience of an estuarine microphytobenthic assemblage under irradiance conditions imposed under laboratory culture and not to examine the effect of the disturbance created by removal of the sediment from the field into the laboratory. A natural microphytobenthic assemblage was observed under 2 reduced light regimes. The response of the assemblage was studied by analysing microphytobenthic species composition (gross assemblage change), biomass (chlorophyll a [chl a]) and pigment composition. Photophysiological status was assessed between the 2 light treatments. If changes in assemblage structure occur rapidly upon entry to a laboratory system, the validity of experiments investigating the effects of further perturbations may be questioned, since the control measurement will no longer be related to the natural system. Therefore, the validity of the approach may rest on how rapidly assemblages change under laboratory conditions.

\section{MATERIALS AND METHODS}

In October 1999, surface sediment from the Eden Estuary was collected. The samples were classified as sand and sandy-mud sediments, whose fine grain fraction $(>0.063 \mu \mathrm{m})$ was between 10 and $25 \%$ (classification after Figge et al. 1980 cited in Riethmüller et al. 1998). The sediment was sieved through a $150 \mu \mathrm{m}$ mesh to remove macrofauna and most meiofauna. A $3 \mathrm{~cm}$ deep layer of sieved, homogenously mixed sediment was placed into 23 sand-filled cores (surface area: $50 \mathrm{~cm}^{2}$ ). Three cores were used for initial measurements, and 20 cores (10 unshaded and 10 shaded) were distributed between 2 tanks in a randomised block design. Shading was provided using a computer-generated black and white pattern, printed onto acetate and placed appropriately onto a thin Perspex lid covering both tanks. A natural tidal regime was simulated (using filtered coastal water of 22 salinity) and the growth chamber maintained temperature at $10^{\circ} \mathrm{C}$. White fluorescent lamps provided a mean photosynthetic photon flux density (PPFD) of $164 \mu \mathrm{mol}$ $\mathrm{m}^{-2} \mathrm{~s}^{-1}$ for unshaded cores and $77 \mu \mathrm{mol} \mathrm{m} \mathrm{m}^{-2} \mathrm{~s}^{-1}$ for shaded cores on a 12:12 h light:dark cycle.

Initial measurements of chl $a$, pigment composition, carbohydrate fractions and assemblage composition (species richness, diversity and low temperature scanning electron microscopy [LTSEM]) were taken from 3 individual cores, $1 \mathrm{~d}$ after sieving the sediment. After $14 \mathrm{~d}$, these same parameters were taken from the 20 cores (10 unshaded and 10 shaded) maintained under experimental conditions. Fluorescence parameters $\left(F_{0}{ }^{15}\right.$, $F_{\mathrm{v}} / F_{\mathrm{m}}$ and photosynthetic-irradiance [P-I] curves) were also taken at the end of the experimental period in order to assess differences in photophysiology between the 2 light treatments.

Low temperature scanning electron microscopy. The sediment structure of the initial assemblage and of the assemblage after $14 \mathrm{~d}$ under the experimental conditions was visualised using LTSEM (Paterson 1995). Surface sediment was removed using strips of stiff foil and plunged into liquid nitrogen. The sediment remained frozen until examination (Oxford cryosystems with Joel 35FC SEM). Heat etching removed most frozen surface water, after which samples were sputter-coated with gold and viewed while still frozen. 
Diatom cell collection. Samples of microphytobenthos were collected by surface scrapes and lens tissue (Eaton \& Moss 1966).

Lens tissue method: To collect the motile epipelic fraction, 2 pieces of lens tissue $\left(2 \mathrm{~cm}^{2}\right)$ were placed on the sediment surface. After $1 \mathrm{~h}$, the top piece of lens tissue was removed with forceps, placed in a labelled Eppendorf and preserved in $1.25 \%$ gluteraldehyde, prior to acid cleaning and permanent slide preparation (Simonsen 1974).

Surface scrape method: A small piece of aluminium was used to remove the surface sediment layer, which was placed in a glass vial, and preserved in $1.25 \%$ gluteraldehyde. This allowed the collection of the entire microphytobenthic assemblage, including diatoms and cyanobacteria.

Cells were counted and identified using a Zeiss Universal light microscope (total magnification: 788x). Where possible, 300 cells per slide were counted. For counts of the whole sediment assemblage, naviculoid species were divided into size fractions (length of small species $\leq 12.75 \mu \mathrm{m}$, length of mid-sized species $=12.75$ to $21.25 \mu \mathrm{m}$, length of large species $\geq 21.25 \mu \mathrm{m}$ ), with the exception of Navicula digitoradiata and $N$. gregaria. Each size group was considered as a taxon.

Fluorometry. Non-invasive fluorescence measurements were made using a FMS2 fluorometer (Hansatech $^{\mathrm{TM}}$ ) on cells that had been dark-adapted for $15 \mathrm{~min}$ (Honeywill et al. in press). Biomass of the cores was estimated using minimum fluorescence $\left(F_{0}{ }^{15}\right)$ (Barranguet \& Kromkamp 2000, Honeywill et al. in press). To examine the possibility that cells within the experimental assemblages were under photophysiological stress, examination of the efficiency of excitation capture by open photosystem 2 (PSII) centres was used. This is also known as the 'Genty factor' ratio (Genty et al. 1989) and is such that:

$$
F_{\mathrm{v}} / F_{\mathrm{m}}=\left(F_{\mathrm{m}}-F_{0}{ }^{15}\right) / F_{\mathrm{m}}
$$

where $F_{\mathrm{m}}$ is maximal fluorescence (dark-adapted), $F_{0}{ }^{15}$ is minimum fluorescence (dark-adapted) and $F_{\mathrm{v}}$ is variable fluorescence (dark-adapted). A ratio of 0.75 indicates a healthy algal cell (C. Honeywill pers. comm.). The Genty factor can be used to calculate the relative linear rate of photosynthetic electron transport:

$$
\text { Relative ETR }=F_{\mathrm{v}} / F_{\mathrm{m}} \times \mathrm{PFD}
$$

where PFD is the photon flux density (Kromkamp et al. 1998). Using the relative ETR, 3 P-I curves from each experimental light treatment were used to calculate photosynthetic affinity $(\alpha)$, maximum photosynthetic rate $\left(P_{\max }\right)$ and the light saturation index $\left(E_{\mathrm{k}}\right)$.

Pigment analysis. From all cores, the upper $4 \mathrm{~mm}$ of sediment was collected using the contact core method (Honeywill et al. in press) and used for pigment analy- sis. High performance liquid chromatography (HPLC), using the method of Wiltshire et al. (1998), allowed for the quantitative determination of pigments. Chl a was expressed as an absolute value, calculated against known standards (Sigma), whilst all other pigments were expressed as a ratio to chl $a$.

Measurement of extracellular carbohydrates. The phenol-sulphuric acid assay was used to quantify the amount of extracellular carbohydrates within the sediments (Dubois et al. 1956). Three fractions were measured: (1) total carbohydrate concentration of the sediment within the range of the assay, including intracellular, extracellular and particle-bound material; (2) total colloidal carbohydrate (liquid phase), which is a useful index of microbial EPS (Decho 1990); and (3) the polymeric fraction of the carbohydrates in the colloidal phase (after Underwood et al. 1995). Absorbance was measured on a spectrophotometer against a reagent blank at $485 \mathrm{~nm}$. Concentration was calibrated against a glucose standard curve and results were expressed as $\mu \mathrm{g}$ glucose equivalents per $\mathrm{g}$ of dry sediment ( $\mu$ g glucose equiv. $\mathrm{g}^{-1}$; Underwood et al. 1995).

Statistics. Kruskal-Wallis test, 1-way analysis of variance (ANOVA), $t$-test and the Mann-Whitney test were used to determine if measured photophysiological parameters where significantly different between experimental light treatments (Zar 1999). Assemblage analysis was carried out using reciprocal averaging (RA) ordination. Since one aim of the experiment was to investigate gross assemblage change, the RA ordination was down-weighted. (The effect of RA ordination without down-weighting was assessed and concluded to be insignificant.) The SIMI similarity index (Medlin 1983) was used to compare assemblages between treatments. The index has a value of 0 when samples have no taxa in common, and of 1 when samples have identical taxa at the same relative abundance. This statistic gives more weight to the abundant taxa.

\section{RESULTS}

\section{Alterations in biochemical parameters}

Chl a content was consistent across the treatments and against initial values, indicating no significant change in biomass over $14 \mathrm{~d}$, either from initial levels or between light treatments (Kruskal-Wallis, $\mathrm{p}=0.242$ ). Mean values $\pm \mathrm{SD}$ were $89.5 \pm 5.3 \mathrm{mg} \mathrm{m}^{-2}, 90.5 \pm$ $18.6 \mathrm{mg} \mathrm{m}^{-2}$ and $107.2 \pm 32.3 \mathrm{mg} \mathrm{m}^{-2}$ for initial, unshaded and shaded assemblages, respectively (Fig. 1A). $F_{0}{ }^{15}$ between experimental light treatments did not differ significantly ( $t$-test, $\mathrm{p}=0.72$ ), having mean values of $375 \pm 149$ and $399 \pm 127$ for unshaded and shaded cores, respectively. 

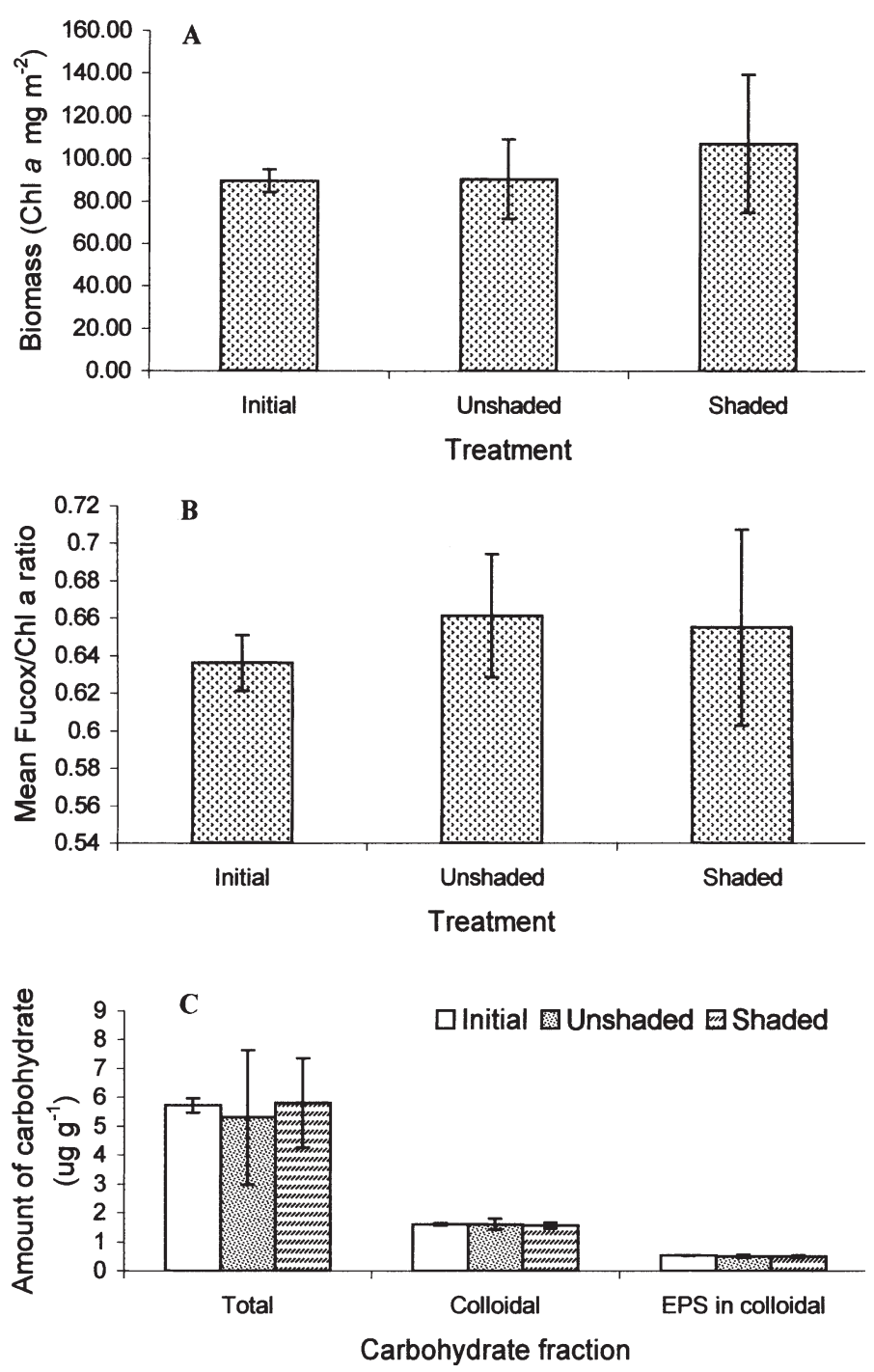

Fig. 1. (A) HPLC-determined mean chlorophyll a (chl a) concentrations for the initial field assemblage and the 2 experimental light treatments (unshaded and shaded). (B) Fucoxanthin/chl $a$ ratios of the initial field assemblage and the 2 experimental light treatments (unshaded and shaded). (C) Relative amounts of extracellular polymeric substances (EPS) from the initial field assemblage and the 2 experimental light treatments (unshaded and shaded). EPS were divided into the 3 fractions of total, colloidal and polymeric in colloidal. In all graphs, error bars represent $\pm \mathrm{SD}_{\text {; for initial }}$ cores, $\mathrm{n}=3$ and for experimental treatments, $\mathrm{n}=10$

Fucoxanthin/chl a ratios did not differ significantly between light treatments and against initial values (1-way ANOVA, $\mathrm{p}=0.659)$, having mean values $\pm \mathrm{SD}$ of $0.64 \pm 0.01,0.66 \pm 0.03$ and $0.66 \pm 0.05$ for initial, unshaded and shaded cores, respectively (Fig. 1B). The relative amounts of EPS (Fig. 1C) found within the sediments of the light treatments did not differ significantly from the initial amounts, or from each other (total carbohydrate, 1-way ANOVA, p $=0.831$; colloidal fraction, 1 -way ANOVA, $\mathrm{p}=0.718$; polymeric in colloidal fraction, 1-way ANOVA, $\mathrm{p}=0.589$ ).

\section{Photophysiology}

$F_{\mathrm{v}} / F_{\mathrm{m}}$ ratios did differ significantly between light treatments, having mean values \pm SD of $0.60 \pm 0.06$ and $0.65 \pm 0.03$ for unshaded and shaded cores, respectively. Both unshaded and shaded assemblages had mean $F_{\mathrm{v}} / F_{\mathrm{m}}$ ratios of less than 0.75 , although this ratio was significantly higher for the shaded experimental cores (Mann-Whitney test, $\mathrm{p}=0.014$; Fig. 2B). Maximum photosynthetic rate, photosynthetic affinity and light saturation values were estimated from P-I curves (Table 1). These photosynthetic parameters did not differ significantly between unshaded and shaded cores (maximum photosynthetic rate, $t$-test, $\mathrm{p}=0.48$; photosynthetic affinity, $t$-test, $\mathrm{p}=0.65$; light saturation values, $t$-test, $\mathrm{p}=0.34$ ).
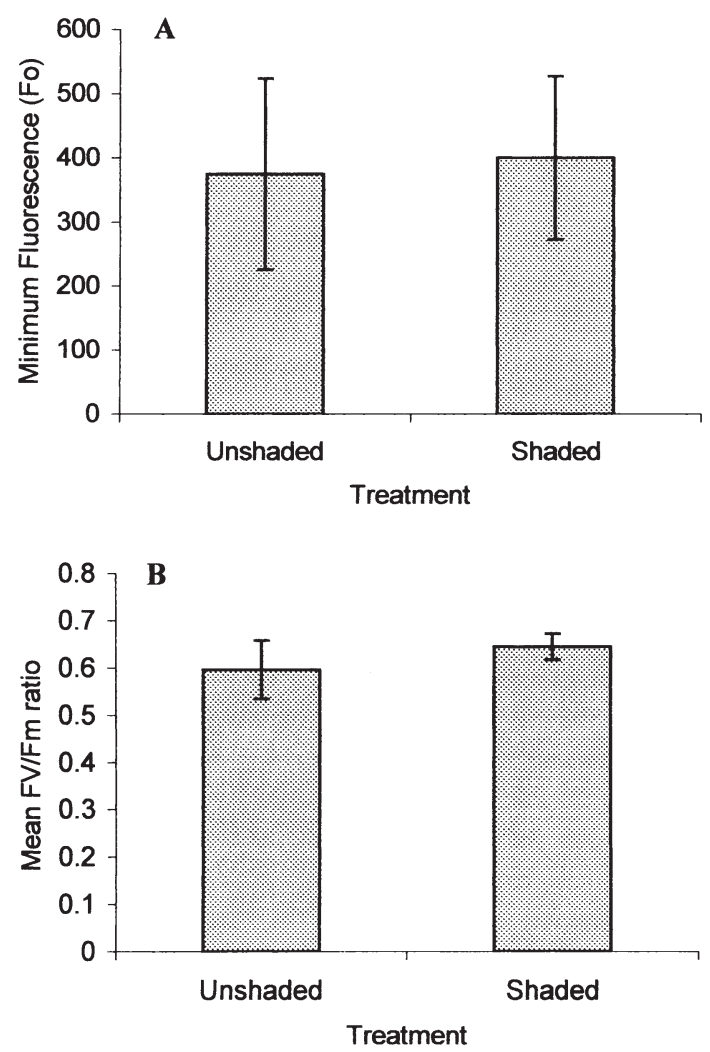

Fig. 2. (A) Biomass as determined by minimum fluorescence for unshaded and shaded cores. (B) Maximum PSII quantum efficiency $\left(F_{\mathrm{v}} / F_{\mathrm{m}}\right)$ for unshaded and shaded cores. Values were obtained after $14 \mathrm{~d}$ under experimental conditions; error bars represent $\pm \mathrm{SD}$; for experimental treatments, $\mathrm{n}=10$ 


\section{Assemblage structure}

Low-temperature scanning electron micrographs demonstrated the development of a confluent biofilm over the surface of the test cores (Fig. 3). The assem- blages varied slightly in composition, but were comprised of a mixed assemblage of mainly diatoms interspersed with other microphytobenthos. The size of diatom cells varied among treatments, with the initial assemblage dominated by Gyrosigma fasciola and
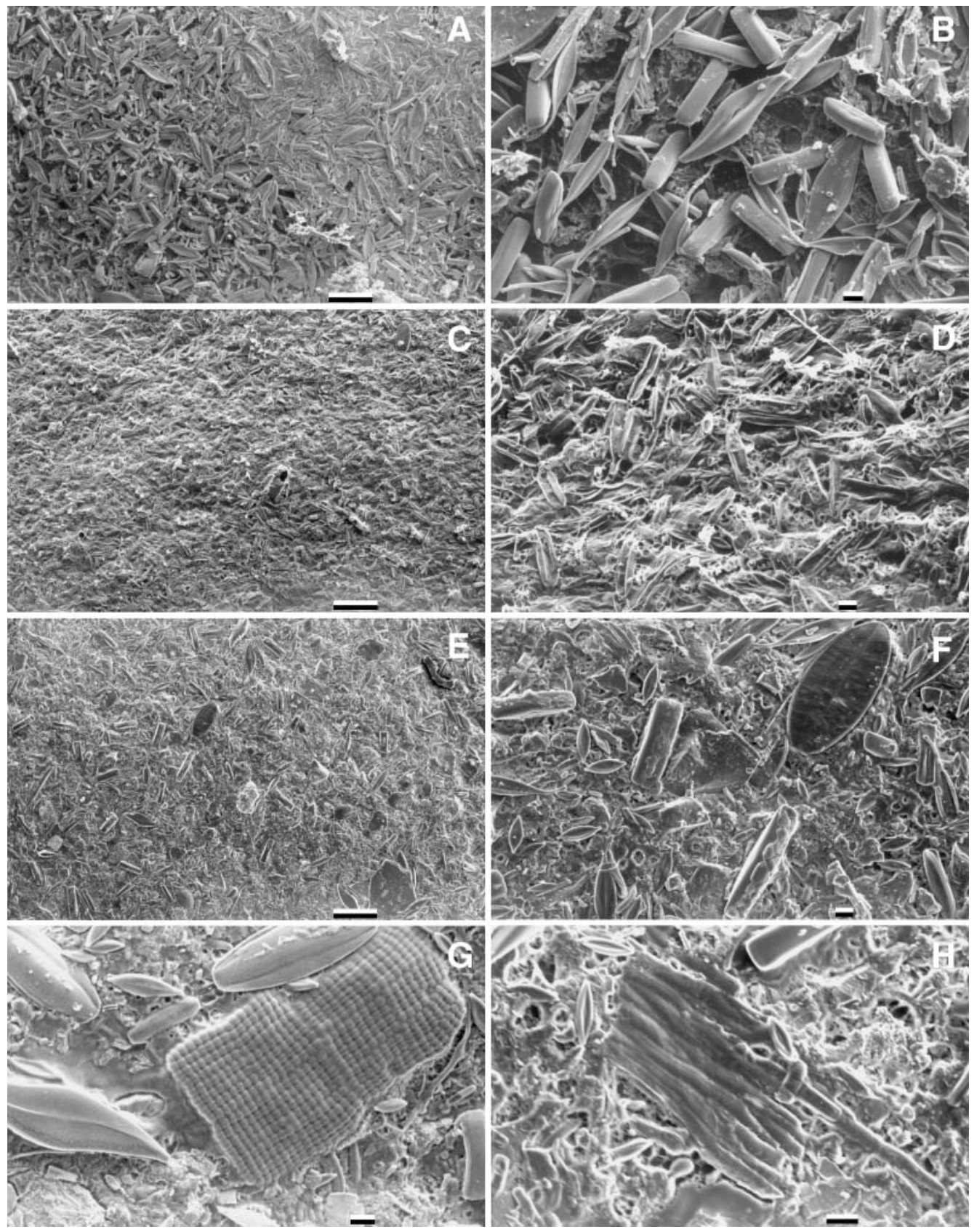

Fig. 3. (A) Surface sediment of the initial diatom dominated assemblage. Scale bar $=100 \mu \mathrm{m}$. (B) Surface sediment of the initial diatom assemblage - abundant species include Gyrosigma fasciola and Pleurosigma angulatum. Scale bar $=10 \mu \mathrm{m}$. (C) Surface sediment of an unshaded core after $14 \mathrm{~d}$. Scale bar $=100 \mu \mathrm{m}$. (D) Surface sediment of an unshaded core after $14 \mathrm{~d}$. Scale bar $=$ $10 \mu \mathrm{m}$. (E) Surface sediment of a shaded core after $14 \mathrm{~d}$. Scale bar $=100 \mu \mathrm{m}$. (F) Surface sediment of a shaded core after $14 \mathrm{~d}$. Scale bar $=10 \mu \mathrm{m}$. (G) Surface sediment of a shaded core. Scale bar $=10 \mu \mathrm{m}$. A mixed diatom assemblage surrounds the tabular colony of Merismopedia punctata. (H) Surface sediment of a shaded core. Scale bar $=10 \mu \mathrm{m}$. A mixed diatom assemblage surrounds a cyanobacterium 
Table 1. Photosynthetic parameters of unshaded and shaded microphytobenthic communities. ETR = electron transport rate. Values are the parameter estimates and the SD is in parentheses where $n=3$ for cores from each experimental treatment

\begin{tabular}{|llcr|}
\hline P-I parameter & Units & $\begin{array}{c}\text { Unshaded } \\
180 \mu \mathrm{mol} \mathrm{m}^{-2} \mathrm{~s}^{-1}\end{array}$ & $\begin{array}{c}\text { Shaded } \\
65 \mathrm{~mol} \mathrm{~m}^{-2} \mathrm{~s}^{-1}\end{array}$ \\
\hline Maximum photosynthetic rate $\left(P_{\max }\right)$ & Relative ETR & $73.1(29.9)$ & $89.4(13.0)$ \\
Photosynthetic affinity $\left(\alpha^{*}\right)$ & Relative ETR & $0.46(0.12)$ & $0.54(0.04)$ \\
Light saturation index $\left(E_{\mathrm{k}}\right)$ & $\mu \mathrm{mol} \mathrm{m}^{-2} \mathrm{~s}^{-1}$ & $154.9(31.4)$ & $165.1(12.5)$ \\
\hline
\end{tabular}

Pleurosigma angulatum (Fig. 3A,B). There was an apparent shift towards dominance by smaller diatom species after $14 \mathrm{~d}$ under laboratory conditions, with this effect being more pronounced for the unshaded experimental assemblage (Fig. 3C-F). The cyanobacterium Merismopodia punctata was found forming rafts on the surface of some samples (Fig. 3G), while other cyanobacteria were also noted as part of the assemblage (Fig. 3H). However, while this qualitative data unequivocally demonstrated the presence of cyanobacteria, numbers were sufficiently low to prevent the cyanobacterial marker pigment, zeaxanthin, being detected by HPLC.
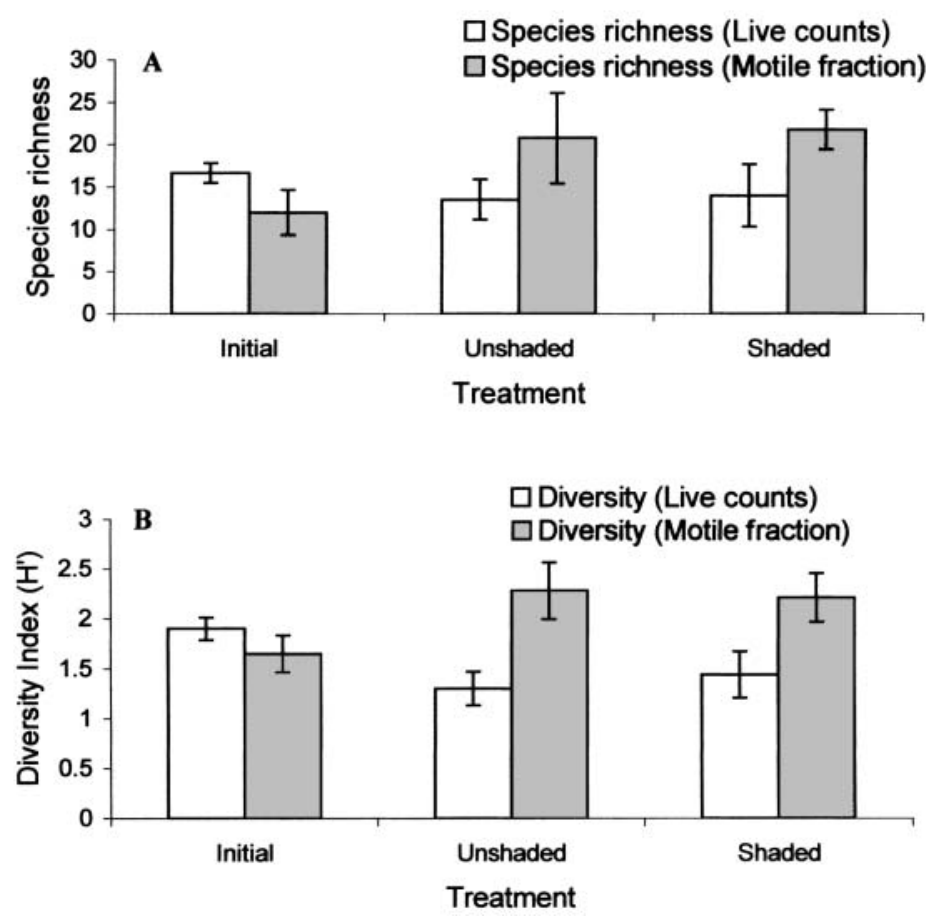

Fig. 4. (A) Species richness of the initial assemblage and experimental assemblages for counts of the motile epipelic fraction and whole sediment assemblage. (B) Diversity of the initial assemblage and experimental assemblages for counts of the motile epipelic fraction and whole sediment assemblage. In both graphs, error bars represent $\pm \mathrm{SD}$; for initial cores, $\mathrm{n}=3$ and for experimental treatments, $\mathrm{n}=4$

\section{Assemblage diversity}

A total of 63 diatom taxa were identified from lens tissue samples. In all treatments, of live and motile counts, $95 \%$ of the overall percentage composition consisted of the epipelic fraction. Cyanobacteria were found in all live samples, at an overall percentage abundance of $<1 \%$. The initial assemblage was found to contain a Gleotheca species and Merismopodia punctata, whilst the experimental cores contained a Cylindrospermum species and an unidentified colonial species.

After $14 \mathrm{~d}$ under the experimental light treatments, species richness (Fig. 4A) and diversity (Fig. 4B) were similar between unshaded and shaded cores for both the motile fraction and whole sediment assemblage. There was no significant difference in species richness between the initial assemblage and the experimental assemblages for the motile epipelic fraction (1-way ANOVA, $p=0.159$ ) and counts of the whole sediment assemblage (1-way ANOVA, $p=0.33$ ). Diversity of the initial assemblage, taking into account the whole sediment assemblage, was found to be significantly higher than the assemblages of the experimental light treatments (1-way ANOVA, $p=0.007$ ), but was not significantly different for the motile epipelic fraction (1-way ANOVA, $p=0.168$ ).

The correspondence of both the motile and whole sediment assemblage samples and species ordinations can be evaluated by comparing Fig. 5A,B. Qualitative LTSEM evidence suggesting that the initial diatom assemblage was made up of larger species was supported by the reciprocal averaging analysis. The initial motile samples were typified by the larger diatom species of Navicula digitoradiata (25 to $80 \mu \mathrm{m}$ long), Gyrosigma balticum (200 to $400 \mu \mathrm{m}$ long), G. fasciola (60 to $150 \mu \mathrm{m}$ long), Pleurosigma angulatum (150 to $360 \mu \mathrm{m}$ long) and Surirella gemma (70 to $140 \mu \mathrm{m}$ long). They were typically grouped to the right on reciprocal averaging Axis 1. With the addition of some smaller Achnanthes species and a small unidentified Navicula species, the initial species composition of the whole sediment assemblage, produced similar findings. Species that typified the experimental light treatment assemblages were grouped to the left on reciprocal averag- 
ing Axis 1. There was little difference in species composition between the 2 experimental light treatments, both being dominated by smallersized naviculoid species. Similarity analysis (Table 2) indicated that the greatest change from the initial assemblage structure occurred for the unshaded cores (SIMI of 0.56 and 0.82 , respectively, for the motile fraction and samples of the whole sediment assemblage). The motile fraction showed greater alteration with time than the samples of the whole assemblage.

\section{DISCUSSION}

\section{Light climate}

When an algal assemblage is placed in a given light regime, species will acclimate within the limits of their genetic potential and environmental constraints. Inter- and intraspecific competition for light may influence the assemblage structure, and vertical partitioning of the light gradient through the sediment could serve as a mechanism of coexistence (Grover 1997). No significant differences were found after $14 \mathrm{~d}$, between the 2 experimental treatments whose irradiance levels were comparable with laboratory-based experiments cited in the literature (Admiraal 1977, Glud et al. 1992, Hay et al. 1993, Madsen et al. 1993, Peletier et al. 1996, Serôdio et al. 1997, Smith \& Underwood 1998) at either a photophysiological level (photosynthetic parameters) or due to assemblage change (species-count data).

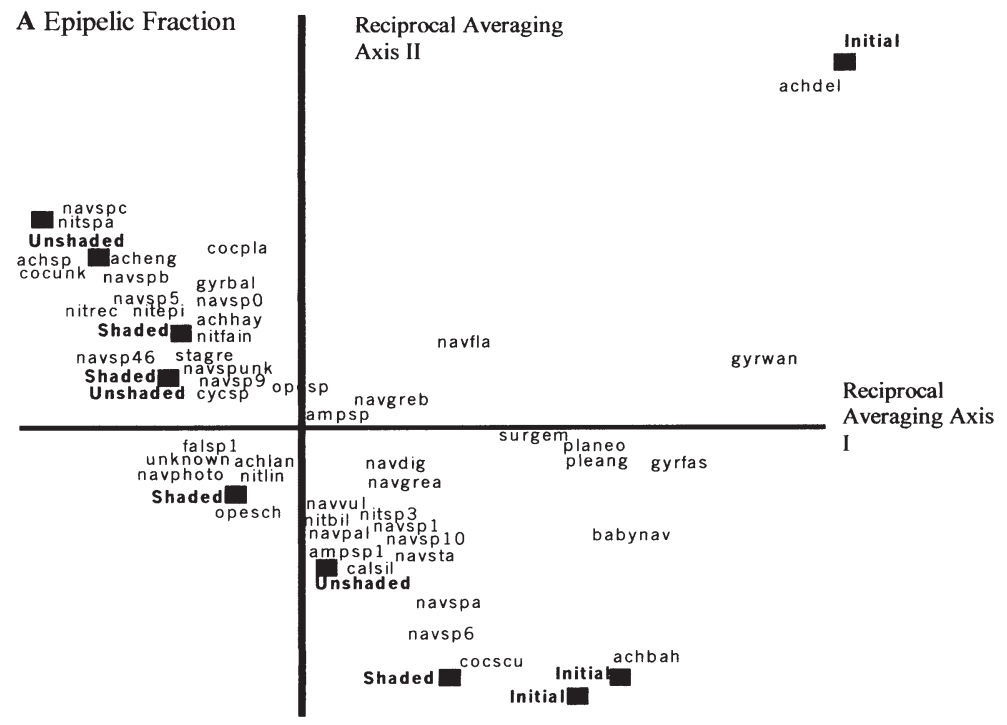

B Whole Sediment Assemblage

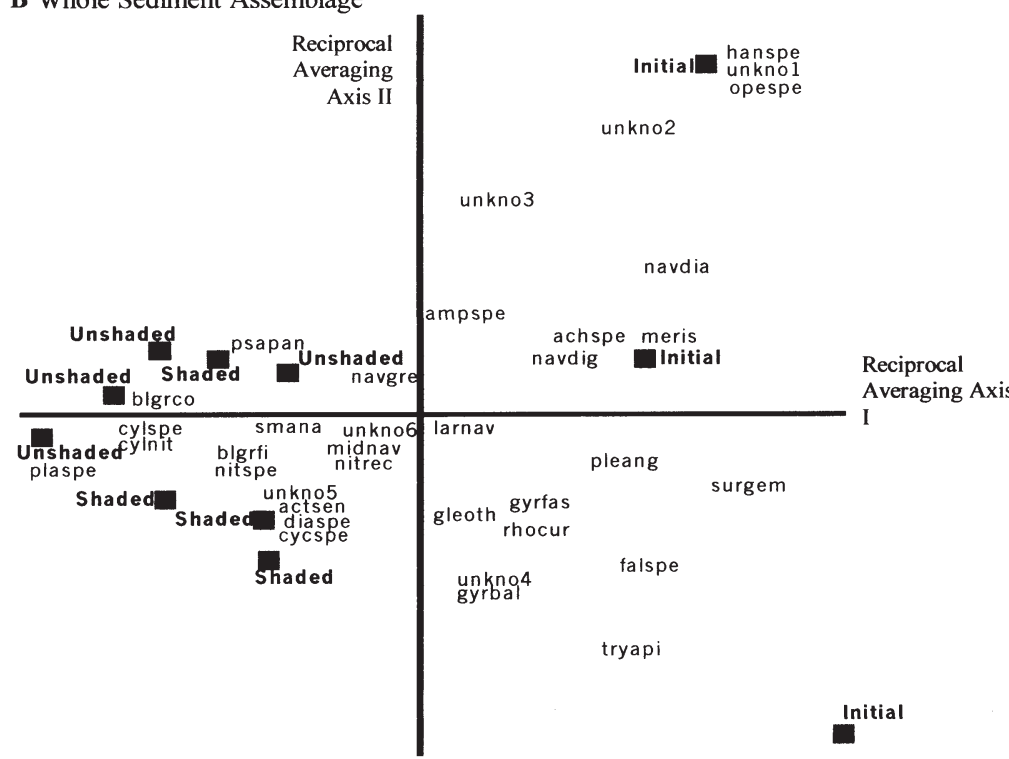

Fig. 5. Characterisation of algal assemblages of the motile epipelon (A) and the whole sediment assemblage (B). For initial cores, $\mathrm{n}=3$, and for experimental treatments, $\mathrm{n}=5$. (A,B) Reciprocal averaging and selected species scores for algal assemblages of unshaded cores, shaded cores and initial samples. Species designations include: achdel = Achnanthes delicatula, acheng = A. engelbrechtii, achhay = A. haynaldii, achlan = A. lanceolata, actsen = Actinoptychus senarius, achspe = Achnanthes sp., achsub = A submarina, ampspe = Amphora sp., ampsp1 = Amphora sp. 1, babynav = unidentified small Naviculoid, blgrco = blue-green colony, calsil $=$ Caloneis silicula, cocpla $=$ Cocconeis placentula, cocscu $=C$. scutellum, cocpel $=C$. peltoides, cocunk $=$ unknown Cocconeis sp., cycspe $=$ Cyclotella sp., cylnit $=$ unknown Cylindrotheca spp., Cylspe $=$ Cylindrotheca sp., cylsper $=C y l i n d r o s p e r-$ mum sp., diaspe $=$ Diatoma sp., diavul = D. vulgare, falspe $=$ Fallacia sp., falsp1 $=$ Fallacia sp. 1, gleoth = Gleotheca sp., gyrbal $=$ Gyrosigma balticum, gyrfas = G. fasciola, gyrwan = G. wansbeckii, hanspe = Hantzschia sp., larnav = large Navicula sp., merpun $=$ Merismopedia punctata, midnav = mid-sized Navicula sp., navdia $=$ unknown $N$. spp., navdig $=N$. digitoradiata, navfla $=N$. fla natica, navgre $=$ Navicula gregaria, navgrea $=N$. gregaria $a$, navgreb $=N$. gregaria $b$, navpal $=N$. palpebralis, navpin $=$ unknown Naviculoid or Pinnularia sp., navphoto = unknown large Naviculoid, navsp0 = unknown Navicula spp. 0, navsp1 = unknown $N$. spp. 1, navsp10 = unknown $N$. spp. 10, navsp46 = unknown $N . \operatorname{spp} .46$, navsp5 = unknown $N . \operatorname{spp} .5$, navsp53 = unknown $N$. spp. 53, navsp6 = unknown $N$. spp. 6, navsp9 = unknown N. spp. 9, navspa = unknown $N$. spp. A, navspb = unknown Navicula sp. $\mathrm{B}$, navspc $=$ unknown Navicula sp. C, navsta $=N$. stankovicii, navvul $=N$. vulpina, nitbil $=$ Nitzschia bilobata, nitdis $=N$. dissipata, nitepi $=N$. epithemioides, nitlin $=N$. linearis, nitrec $=N$. recta, nitfain $=$ unknown $N$. spp., nitspe $=N$. spp., nitspunk $=$ unknown Nitzschia spp., opespe $=$ unknown Opephora spp., opesch $=O$. schwartzii, planeo $=$ Plagiotropis neovitrea, plaspe $=$ unknown Plagiotropis spp., pleang = Pleurosigma angulatum, psapan $=$ Psammodictyon pandiformis, rhocur $=$ Rhoicosphenia curvata smanav = small-sized Navicula spp., stagre = Stauroneis gregorii, surgem = Surirella gemma, surspa = unknown Surirella spp., tryapi = Tryblionella apiculata, unkno1-6 = unknown spp. 1-6, unknown $=$ unknown spp. 
Table 2. Comparison of diatom assemblages from the motile epipelic fraction and whole sediment assemblage. Similarity indices range from 0 , when samples have no taxa in common, to 1 , when samples have the same taxa and relative abundance

\begin{tabular}{|lcc|}
\hline & $\begin{array}{c}\text { Motile epipelic } \\
\text { fraction }\end{array}$ & $\begin{array}{c}\text { Whole sediment } \\
\text { assemblage }\end{array}$ \\
\hline $\begin{array}{c}\text { Initial assemblage vs } \\
\text { Unshaded assemblage }\end{array}$ & 0.56 & 0.82 \\
$\begin{array}{c}\text { Initial assemblage vs } \\
\text { Shaded assemblage }\end{array}$ & 0.71 & 0.83 \\
$\begin{array}{l}\text { Unshaded assemblage vs } \\
\text { Shaded assemblage }\end{array}$ & 0.90 & 0.99 \\
\hline
\end{tabular}

Diatom communities in an environment characterised by low ambient irradiances usually have increased photosynthetic efficiency (increased $\alpha$ ), lower photosynthetic rates at saturating irradiances (lower $P_{\max }$ ) and a decreased saturation parameter (lower $E_{\mathrm{k}}$ ) (Hill 1996). Monoculture studies of epipelic diatoms illustrate that differences in photosynthetic parameters $\left(\alpha, P_{\max }\right.$ and $\left.E_{\mathrm{k}}\right)$ between species do occur (Admiraal 1984), and thus changes in the taxonomic structure of a diatom assemblage could potentially alter fluorescence parameters. Photosynthetic responses were not significantly different between the 2 experimental light treatments (Table 1), which gave the first indication that experimental assemblages were similar in their composition. However, care should still be exercised since more extreme differences between laboratory light treatments may still produce changes in photophysiology. Changes between ambient light levels and laboratory cultures are likely to be more extreme in summer than in winter.

Acclimation to lower photon fluxes is commonly reflected by increased levels of chlorophyll proteins (Falkowski \& Raven 1997). For example, MacIntyre et al. (1996) found high fucoxanthin/chl a ratios to be indicative of low light acclimation in phytoplankton. Additionally, accessory pigments such as chl $C$ and fucoxanthin have been shown to be especially important in ensuring maximum photosynthetic capacity (Gallagher et al. 1984). Hust et al. (1999) found that in shading experiments using diatom-dominated sediment from the Wadden Sea, shaded sediment areas generally contained higher amounts of light harvesting subunits. No significant differences in fucoxanthin/ chl a ratios between experimental treatments and the initial assemblage were observed in this experiment, possibly because irradiance levels in the field during October were quite low so that assemblages are already adapted to reduced light intensity before transplantation into the laboratory culture conditions.
Most cyanobacteria are shade-adapted organisms (Stal 1995) and studies have shown filamentous cyanobacteria to be positioned under the diatom layer (Underwood \& Kromkamp 1999 and references therein). With the reduced light climate imposed in this experiment, there was a risk that the cyanobacteria might have out-competed the diatoms and consequently dominated the assemblage. However, the experimental assemblage structure remained diatom-dominated even after $14 \mathrm{~d}$ under experimentally reduced light intensities, and only a small proportion of cyanobacteria were identified using both light microscopy and LTSEM. Populations of cyanobacteria may have been limited by other factors such as sediment size and temperature (Stal 1995, Watermann et al. 1999).

\section{Physiological stress}

The $F_{\mathrm{v}} / F_{\mathrm{m}}$ ratio reflects the probability of PSII reaction centres using the available excitation energy for photochemistry. Environmental stresses that affect PSII efficiency, lead to a characteristic decrease in $F_{\mathrm{v}} / F_{\mathrm{m}}$, with a ratio of 0.75 indicating a healthy algal cell (C. Honeywill pers. comm.). The $F_{\mathrm{v}} / F_{\mathrm{m}}$ ratio of assemblages from both experimental light treatments indicated signs of stress, which could be attributable to the reduced light intensities of the experimental system, or perhaps some other limiting factor such as nutrient availability. Flameling (1998) and Kromkamp \& Peene (1999) have shown low $F_{\mathrm{v}} / F_{\mathrm{m}}$ values to be indicative of nutrient limitation.

\section{Diversity}

The highest assemblage diversity $\left(H^{\prime}\right)$ was found in surface scrapes from the initial assemblage, and these were significantly more diverse than those from experimental assemblages, although separating the Navicula species into 3 size fractions (length of small species $\leq 12.75 \mu \mathrm{m}$, length of mid-sized species $=12.75$ to $21.25 \mu \mathrm{m}$, length of large species $\geq 21.25 \mu \mathrm{m}$ ) could have influenced these values. Also, a degree of error is associated with counts of the motile epipelic fraction, since the species assemblage data presented here included empty frustules. However, this error was probably small.

Reciprocal averaging (Fig. 5A,B) and LTSEM images (Fig. 3A-H) highlighted the change in the diatom assemblage from the initial assemblage after exposure to the experimental treatments. Diversity was marginally reduced at the expense of larger species. Cell size is known to influence many properties of algal cells, including competitive ability (Grover 1989 and refer- 
ences therein), and smaller taxa may become more dominant for the following reasons. In studies of marine and freshwater phytoplankton, the majority of species have shown some increase in cell volume with increasing irradiance (Thompson et al. 1991 and references therein). Larger algae often have higher light requirements due to intra- and intercellular selfshading, and higher minimum nutrient requirements. Larger cells are also more resistant to grazing (Leibold 1999) and so the removal of grazers from the assemblages may have favoured smaller cells. If the reduction in maximum PSII quantum efficiency (Fig. 2B) indicates nutrient limitation, then cells of a smaller size may have been favoured given that their surface area/volume ratio improves their ability to sequester nutrient resources from the surrounding environment (Thompson et al. 1991). Dunaliella tertiolecta adapted to lower light irradiances was shown to divert biosynthesis away from lipids and carbohydrates, and into light-harvesting chlorophyll-protein complexes (Berner et al. 1989). Small size may be an advantage in lowlight environments since the amount of energy available for division may be reduced.

A gradient from right to left along reciprocal averaging Axis 1, of both the motile and whole sediment fractions, indicates that light intensity could be a factor regulating diatom assemblage composition, since both experimental light intensities were much lower than average October field conditions. However, it could also describe the result of moving a natural microphytobenthic assemblage into a laboratory environment where perhaps other factors, such as nutrient availability, could be limiting.

\section{General conclusions}

It is a considerable problem to understand the natural factors that drive ecosystem structure and function in nature (May 1999). Mixtures of assemblages ranging in complexity from 2 species systems, such as the classic experiments of Gause (1934) to increasingly complex mixtures (Huisman \& Weissing 1999, Emmerson et al. 2001) have been used previously. However, a reductionist approach has profound limitations for the understanding of natural interactions in complex systems. The ultimate aim would be to conduct experiments in nature, although this is often impractical. Therefore, the use of manipulated natural assemblages maintained in the laboratory provide a useful model system to study ecological theory such as (1) the intermediate disturbance hypotheses (IDH, Connell 1978); (2) the grazer reversal hypothesis (Proulx \& Mazumder 1998); and (3) aspects of ecosystem function (Emmerson et al. 2001). Indeed, this approach is already being used by a number of authors (Serôdio et al. 1997, Yallop et al. 2000).

In the absence of perturbations, it was not known how rapidly a microphytobenthic assemblage would change under laboratory conditions. In theoretical terms, with a conservative doubling time of $24 \mathrm{~h}$, change in assemblage structure could be rapid. We demonstrate a clear drift toward smaller cells, but without any substantive change in richness or total diversity between systems. In this paper, we do not address causal mechanisms but suggest this information is important given that systems examined in a state of change may lead to idiosyncratic responses and dubious conclusions.

Whilst the stability of natural microphytobenthic communities has been observed for shallow water coastal sandy sediments (Sundbäck et al. 1990, Nilsson et al. 1991, Sundbäck \& Snoeijs 1991), it has yet to be discussed for muddy intertidal estuarine sediments. Results from this study suggest that major changes occur relatively slowly under the specific experimental conditions outlined. Despite perturbations such as sediment sieving, reduced light and a fixed temperature regime, the system was relatively slow to respond. However, in a variable and unpredictable environment, such as an estuary, only a community that is dynamically robust would be expected to persist. Intertidal sediments are exposed to strong vertical gradients and regularly influenced by tidal inundation, and are thus far more variable and dynamic than phytoplankton systems. Indeed, intertidal estuarine sediments are recognised as stressful, depauperate systems, due partly to sudden changes in conditions (i.e. temperature variation, salinity, erosion, deposition). The organisms that can cope with the natural environmental stress can reach a high biomass, but they must be adapted to cope with these variable and changing conditions in a poorly buffered system. Thus microphytobenthic assemblages appear to possess, in contrast to phytoplankton communities, a certain degree of inertia when brought from natural field conditions into the laboratory. These assemblages provide a useful experimental model provided the experimenters are aware that slow changes in species composition are occurring. However, the final test of theory should always be made in the field.

Acknowledgements. Thanks go to Irvine Davidson for help with the LTSEM analysis, and all members of the SERG laboratory and Harold-Mitchell Building. This work was funded by NERC grant GT/04/99/MS/269; this support is gratefully acknowledged.

\section{LITERATURE CITED}

Admiraal W (1977) Influence of light and temperature on the growth rate of estuarine benthic diatoms in culture. Mar Biol 39:1-9 
Admiraal W (1984) The ecology of sediment-inhabiting diatoms. Prog Phycol Res 3:269-322

Barranguet C, Kromkamp J (2000) Estimating primary production rates from photosynthetic electron transport in estuarine microphytobenthos. Mar Ecol Prog Ser 204: 39-54

Begon M, Harper JL, Townsend CR (1990) Ecology: individuals, populations and communities, 2nd edn. Blackwell Scientific Publications, Oxford

Bennion H, Juggins S, Anderson NJ (1996) Predicting epilimnetic phosphorus concentrations using an improved diatom-based transfer function and its application to lake eutrophication management. Environ Sci Technol 30: 2004-2007

Berner T, Dubinsky Z, Wyman K, Falkowski PG (1989) Photoadaptation and the 'package effect' in Dunaliella tertiolecta (Chlorophyceae). J Phycol 25:70-78

Cameron NG (1995) The representation of diatom communities by fossil assemblages in a small acid lake. J Paleolimnol 14:185-223

Connell JH (1978) Diversity in tropical rainforests and coral reefs. Science 199:1302-1310

Decho AW (1990) Microbial exopolymer secretions in ocean environments: their role(s) in food webs and marine processes. Oceanogr Mar Biol Annu Rev 28:73-153

Dickinson G, Murphy K (1998) Ecosytems. Routledge, London

Dubois M, Giles KA, Hamilton JK, Reber PA, Smith F (1956) Colorimetric method for determination of sugars and related substances. Anal Chem 28:350-356

Eaton JW, Moss B (1966) The estimation of numbers and pigment contents in epipelic algal populations. Limnol Oceanogr 11:584-595

Emmerson M, Solan M, Emes C, Paterson DM, Raffaelli D (2001) Idiosyncratic effects of species diversity on ecosystem function. Nature 411:73-77

Falkowski PG, Raven JA (1997) Aquatic photosynthesis. Blackwell Scientific Publications, Abingdon, Oxon

Figge K, Köster R, Thiel HP, Wieland P (1980) Schlickuntersuchungen im Wattenmeer der Deutschen Bucht (Zwischenbericht über ein Forschungsprojekt des KFKI). Die Küste 35:187-204

Flameling I (1998) Growth and photosynthesis of eukaryotic microalgae in fluctuating light conditions, induced by vertical mixing. PhD thesis, Universität Rostock

Gallagher JC, Wood AM, Alberte RS (1984) Ecotypic differentiation in the marine diatom Skeletonema costatum: the influence of light intensity on the photosynthetic apparatus. Mar Biol 82:121-134

Gause GF (1934) The struggle for existence. University of Moscow (available at: www.ggause.com/Contgau.htm)

Genty B, Briantais J, Baker NR (1989) The relationship between the quantum yield of photosynthetic electron transport and quenching of chlorophyll fluorescence. Biochim Biophys Acta 990:87-92

Glud RN, Ramsing NB, Revsbach NP (1992) Photosynthesis and photosynthesis-coupled respiration in natural biofilms quantified with oxygen microsensors. J Phycol 28:51-60

Grover JP (1989) Influence of cell shape and size on algal competitive ability. J Phycol 25:402-405

Grover JP (1997) Resource competition. Chapman \& Hall, London

Hay SI, Maitland TC, Paterson DM (1993) The speed of diatom migration through natural and artificial substrata. Diatom Res 8:371-384

Hill W (1996) Effects of light. In: Stevenson RJ, Bothwell ML, Lowe RL (eds) Algal ecology. Academic Press, London

Honeywill C, Paterson DM, Hagerthey SE (in press) Instant determination of microphytobenthic biomass using fluorescence. Eur J Phycol

Huisman J, Weissing FJ (1999) Biodiversity of plankton by species oscillations and chaos. Nature 402:407-410

Hust M, Krumbein WE, Rhiel E (1999) An immunochemical in situ approach to detect adaptation processes in the photosynthetic apparatus of diatoms of the Wadden Sea sediment surface layers. J Microbiol Meth 28:69-80

Kromkamp J, Limbeek M (1993) Effect of short-term variation in irradiance on light harvesting and photosynthesis of the marine diatom Skeletonema costatum: a laboratory study simulating vertical mixing. J Gen Microbiol 139: $2277-2284$

Kromkamp J, Peene J (1999) Estimation of phytoplankton photosynthesis and nutrient limitation in the eastern Scheldt estuary using variable fluorescence. Aquat Ecol 33:101-104

Kromkamp J, Barranguet C, Peene J (1998) Determination of microphytobenthos PSII quantum efficiency and photosynthetic activity by means of variable chlorophyll fluorescence. Mar Ecol Prog Ser 162:45-55

Leibold LA (1999) Biodiversity and nutrient enrichment in pond plankton communities. Evol Ecol Res 1:73-95

MacIntyre HL, Geider RJ, McKay RM (1996) Photosynthesis and regulation of Rubisco activity in net phytoplankton from Delaware Bay. J Phycol 32:718-731

Madsen KN, Nilsson P, Sündback K (1993) The influence of benthic microalgae on the stability of a subtidal sediment. J Exp Mar Biol Ecol 170:159-177

May R (1999) Unanswered questions in ecology. Phil Trans R Soc Lond B 354:1951-1959

McCormick PV, Cairns J (1994) Algae as indicators of environmental change. J Appl Phycol 6:509-526

Medley CN, Clements WH (1998) Responses of diatom communities to heavy metals in streams: the influence of longitudinal variation. Ecol Appl 8:631-644

Medlin LK (1983) Community analysis of epiphytic diatoms from selected species of macroalgae collected along the Texas coast of the Gulf of Mexico. PhD thesis, A \& M University, Austin, TX

Metaxas A, Lewis AG (1991) Interactions between two species of marine diatoms - effects on their individual copper tolerance. Mar Biol 109:407-415

Nilsson C, Sundbäck K (1991) Growth and nutrient-uptake studied in sand-agar microphytobenthic communities. J Exp Mar Biol Ecol 153:207-226

Olaizola M, Yamamoto HY (1994) Short-term response of the diadinoxanthin cycle and fluorescence yield to high irradiance in Chaetoceros muelleri (Bacillariophyceae). J Phycol 30:606-612

Paterson DM (1995) Biogenic structure of early sediment fabric visualized by low-temperature scanning electron microscopy. J Geol Soc Lond 152:131-140

Paterson DM, Hagerthey SE (2001) Microphytobenthos in contrasting coastal ecosystems: biology and dynamics. In: Reise K (ed) Sandy and muddy shores: ecological comparisons. Ecological studies. Springer-Verlag, Berlin, p 105-126

Peletier H, Gieskes WWC, Buma AGJ (1996) Ultraviolet-B radiation resistance of benthic diatoms isolated from tidal flats in the Dutch Wadden Sea. Mar Ecol Prog Ser 135: 163-168

Petchey OL, McPhearson PT, Cassey TM, Morin PJ (1999) Environmental warming alters food-web structure and ecosystem function. Nature 401:69-72

Peterson G, Allen CR, Holling CS (1998) Ecological resilience, biodiversity and scale. Ecosystems 1:6-18 
Proulx M, Mazumder A (1998) Reversal of grazing impact on plant species richness in nutrient-poor vs nutrient-rich ecosystems. Ecology 79:2581-2592

Riethmüller R, Hakvoort JHM, Heineke M, Heymann K, Kühl H, Witte G (1998) Relating erosion threshold to tidal flat surface colour. In: Black KS, Paterson DM, Cramp A (eds) Sedimentary processes in the intertidal zone, Vol 139. Geological Society Special Publication, London, p 283-293

Serôdio J, da Silva JM, Catarino F (1997) Nondestructive tracing of migratory rhythms of intertidal benthic microalgae using in vivo chlorophyll a fluorescence. J Phycol 33: $542-553$

Simonsen R (1974) The diatom plankton of the Indian Ocean expedition of R/V Meteor 1964-5. Meteor Forschergeb Reihe D Biol 19:1-107

Smith DJ, Underwood GJC (1998) Exopolymer production by intertidal epipelic diatoms. Limnol Oceanogr 43:1578-1591

Staats N, Stal LJ, Mur LR (2000) Exopolysaccharide production by the epipelic diatom Cylindrotheca closterium: effects of nutrient conditions. J Exp Mar Biol Ecol 249: $13-27$

Stal LJ (1995) Physiological ecology of cyanobacteria in microbial mats and other communities. Tansley Review No. 84. New Phytol 131:1-32

Sundbäck K, Snoeijs P (1991) Effects of nutrient enrichment on microalgal community composition in a coastal shallow-water sediment system-an experimental study. Bot Mar 34:341-358

Sundbäck K, Jonsson B, Nilsson P, Lindstrom I (1990) Impact of accumulating drifting macroalgae on a shallow-water sediment system-an experimental study. Mar Ecol Prog Ser 56:261-274

Sundbäck K, Enoksson V, Graneli W, Pettersson K (1991) Influence of sublittoral microphytobenthos on the oxygen and nutrient flux between sediment and water: a labora-

Editorial responsibility: Otto Kinne (Editor),

Oldendorf/Luhe, Germany tory continuous flow study. Mar Ecol Prog Ser 74:263-279

Thompson PA, Harrison PJ, Parslow JS (1991) Influence of irradiance on cell volume and carbon quota for ten species of marine phytoplankton. J Phycol 27:351-360

Tilman D (1999) The ecological consequences of changes in biodiversity: a search for general principles. Ecology 80: 1455-1474

Underwood GJC, Kromkamp J (1999) Primary production by phytoplankton and microphytobenthos in estuaries. Adv Ecol Res 29:93-153

Underwood GJC, Provot L (2000) Determining the environmental preferences of four estuarine epipelic diatom taxa: growth across a range of salinity, nitrate and ammonium concentrations. Eur J Phycol 35:173-182

Underwood GJC, Paterson DM, Parkes RJ (1995) The measurement of microbial carbohydrate exopolymers from intertidal sediments. Limnol Oceanogr 40:1243-1253

van Donk E, Kilham SS (1990) Temperature effects on silicon and phosphorus limited growth and competitive interactions among three diatoms. J Phycol 26:40-50

Watermann F, Hillebrand H, Gerdes G, Krumbein WE, Sommer U (1999) Competition between benthic cyanobacteria and diatoms as influenced by different grain sizes and temperatures. Mar Ecol Prog Ser 187:77-87

Wiltshire KH, Tolhurst T, Paterson DM, Davidson I, Gust G (1998) Pigment fingerprints as markers of erosion. In: Black KS, Paterson DM, Cramp A (eds) Sedimentary processes in the intertidal zone, Vol 139. Geological Society Special Publication, London, p 99-114

Yallop ML, Paterson DM, Wellsbury P (2000) Interrelationships between rates of microbial production, exopolymer production, microbial biomass and sediment stability in biofilms of intertidal sediments. Microb Ecol 39:116-127

Zar JH (1999) Biostatistical analysis, 4th edn. Prentice-Hall, New York

Submitted: April 30, 2001; Accepted: March 7, 2002

Proofs received from author(s): July 9, 2002 